\title{
THE ILLUSIONS OF PHALLIC AGENCY Invisible Man, Totem and Taboo, and the Santa Claus Surprise
}

\author{
by Douglas Steward
}

In the past decade, queer theory has sparked a renewed interest in the flagging field of high theory, driven largely by the poststructuralist projects of Judith Butler, Teresa de Lauretis, and Eve Sedgwick. Such dense, yet ethereal, theorizing has often attracted negative attention for its failure, in Nancy Fraser's words, to "overcome or at least ameliorate the asymmetries in current practices of subjectivation" or to "construct practices, institutions, and forms of life in which the empowerment of some does not entail the disempowerment of others" (68). Butler, for her part, has nevertheless recently argued that "theoretical wisdom must have a certain measure of autonomy from practical wisdom" if it is to thrive (266). It seems to me that both these views are correct, in their own ways, and that Barbara Christian's influential essay "The Race for Theory" continues to suggest a way of negotiating the space between them. In that essay, Christian makes the case that theory takes place in literary texts in ways that are just as interesting and sophisticated as what theoretical writing per se has to offer and that an over-reliance on the highly specialized language of poststructuralism, divorced from life experience, tends to buttress a hierarchy of white privilege. Taking to heart Christian's plea that we look to literature by people of color as much as we do to Ivory Tower philosophizing for theoretical insight, this essay explores the engagement that Ralph Ellison's 1952 novel Invisible Man makes with the sorts of theoretical concerns that have preoccupied much queer theory: questions of political speech and agency, of gender's articulation with and against sexuality, and of the cultural crosshatching of sexuality with other axes of identification, notably race. I argue that in Ellison's novel the narrator eventually confronts phallocentric representational strategies as illusions of masculine agency, since he continually fails to acquire the sorts of instrumentalities of power associated with directly political forms of speech that are articulated in phallic terms. Indeed, the novel's frequent recourse to castration imagery ultimately typifies its abandonment of the heteronormative phallus' usual association with privileged social agency. In the face of a male-dominated post-war intellectual scene given over to liberal humanist voluntarism, Ellison's novel poses troubling questions that queer theory has recently explored further in its critiques of agency and the phallus. The following discussion will argue that Ellison's novel offers a remarkable—but remarkably overlooked—rejection of the phallus' usual presumption of authority and agency.

In order to appreciate fully the radical gesture that Invisible Man makes in rejecting the phallus as the sine qua non of (masculine) agency, we need first to recall the place 


\section{A L L A L O O}

that castration, both literal and figurative, has played in the history of black-white relations and in the history of representing African-American men in the U.S. Ellison himself offers a chilling commentary on this bloody history in his second short story, "The Birthmark," which was published in New Masses in 1940. In this story, the police request that siblings Matt and Clara identify a black man who, according to the police, has been hit by a car. Matt intends to identify their brother, Willie, by a distinguishing birthmark. After pulling back the body's covering, Matt's gaze is arrested by the lack of an obscure "it." According to the context, the "it" should be the distinguishing birthmark; however, the text twists back on the ambiguity of the "it," retroactively clarifying that "it" was not the birthmark but the genitals: "he gave a start: where it should have been was only a bloody mound of torn flesh and hair. Matt went weak. He felt as though he had been castrated himself" (16). This reaction is, of course, exactly what Willie's lynch squad desired, and the officials present make the symbolic import of the killing and castration fairly explicit when one insists that Willie was hit by a car, not lynched, and another enjoins: "you better remember that, nigger [...] And your sister better remember that, too. 'Cause a car might hit you" (17). At the end of the story, Matt meekly acquiesces and agrees to remember that Willie was hit by a car, suggesting that Willie's literal castration has resulted in his brother's social castration: he is unable to speak out against this phallic expression of white power. As figures of white patriarchy, the police thus enact an Oedipal scenario, threatening brother and sister alike with the same symbolic but deadly castration they have already enacted on Willie, whose name ironically echoes what was taken violently from him.

This theme of literal or figurative social castration recurs persistently in Ellison's work. As Frederick L. Radford notes in "The Journey Towards Castration: Interracial Sexual Stereotypes in Ellison's Invisible Man," the novel of a dozen years later also "has parallel drives towards sexual and social castration" (228). Throughout his marvelously crafted novel and the compelling essays collected in Shadow and Act (SA) and Going to the Territory (GT), Ellison confronts not only the ways in which "race became a major cause, form, and symbol of the American hierarchical psychosis" (GT 336) but also the ways in which historically determined constructions of gender identity buttress those damaging ideological configurations of race. Like Radford, I contend that these race and gender constructions often decussate as sexual and social castration, and in representing castration in this way, Ellison situates himself in a long tradition of writing by African-American men that figures empowerment as a recovery of stolen manhood. ${ }^{1}$ However, whereas "The Birthmark" represents castration as a clear defeat, Invisible Man more complexly investigates the discursive formation of agency as it is articulated not only in terms of race but also of gender and sexuality, ultimately rejecting the hetero- and phallocentric formation of agency that symbolic castration subtends.

\section{Homophobic Logic, Homosocial Sublimation}

However, it may at first appear that Ellison's novel simply repeats the trope of castration-as-disempowerment that has characterized so much of African-American 


\section{A L L A L O O}

men's writing on the struggle for freedom, implicitly inscribing the struggle for freedom in terms that exclude women and homosexuals. Indeed, in a brilliant analysis of the battle royal scene, Daniel Y. Kim has extended the feminist analysis of the novel undertaken by Claudia Tate and others ${ }^{2}$ by arguing in "Invisible Desires: Homoerotic Racism and Its Homophobic Critique in Ralph Ellison's Invisible Man" that the novel also underwrites a "latent homophobic logic" (321).

Kim extends feminist critiques of Ellison's representations of women to include a critique of the narrator's identifications with women and of the novel's representation of homosexuality. In particular, Kim offers a detailed examination of the first chapter's battle royal, in which the white patriarchs of the narrator's town stage an erotic spectacle wherein the black boys act as "a kind of human scrim" across which the patriarchs view the naked blonde (314). As Michel Fabre and Kim both imply, Ellison's description of the "black cigars" (IM 17) on which the white men suck establishes a highly eroticized dynamic between the white men and the black boys, who have visible erections (Fabre 121, Kim 313). For the present discussion, this scene is especially important because it evokes disempowerment as castration. Although the narrator believes that he has come to deliver a speech and believes in the speech he will deliver, the humiliating sexual events of the erection spectacle and the battle royal violently negate the liberal humanist scenario of empowerment through education and rational yet humble speaking (à la Booker T. Washington) that the narrator obstinately continues to fantasize throughout his ritual debasement. Rather than empowerment, the narrator finds symbolic castration, both as a speaking subject and as a male body. ${ }^{3}$ Under the kind of Lacanian theory elaborated in Laura Mulvey's well-known essay "Visual Pleasure and Narrative Cinema," man is positioned as the bearer of the objectifying look. ${ }^{4}$ In this scene, however, the town patriarchs make contradictory demands on the black boys: "Some threatened us if we looked," the narrator recounts, "and others if we did not" (IM 19-20). Psychically split, the narrator is unsure whether the woman is an object of sexual desire, a sexual threat, or a fellow victim. He thus desires at once "to caress her and destroy her" and sees "the terror and disgust in her eyes almost like [his] own terror" $(19,20)$. Remarking on this simultaneous attraction, revulsion, and identification, Kim argues that the "misogyny of the narrator's response" to the woman, when he wants to kill her, "is produced by his awareness of how the woman's 'castration' mirrors his own" (316). As in the diction of certain of Ellison's essays, "castration" or impotence is here inscribed as the privileged figure for the social agent's lack, and in the novel this castration takes on the peculiar form of "invisibility" as well. Thus, the erection spectacle operates to position the black boys as the erotic objects of the white homosocial gaze while simultaneously excluding them from the advantage that homosociality confers on the white men.

As the linchpin in his exegesis of the latent homophobic logic of Ellison's novel, Kim draws attention to an excerpt from the novel, "Out of the Hospital and Under the Bar," published in 1963, that Ellison did not include in the final draft. In this piece, the "latent" homophobic logic evident in other parts of the novel is explicitly articulated when an aggressive white man makes sexual advances on the narrator. Kim concludes that this episode confirms the novel's general, but usually latent, premise that "white 
men seek to subordinate black men because that subordination enables them to use the black male body to gratify an erotic desire that is essentially homosexual" (324, italics omitted). Just as feminists such as Marilyn Frye and Luce Irigaray have attacked male homosexuality as the secret libidinal motive of phallocentrism, so does Ellison's work appear to impugn it as a libidinal motive of racism. This excerpt thus throws Ellison's inscription of homosexuality into relief and suggests that the scene in which the narrator does meet a homosexual, young Emerson, is not without implications for an analysis of Ellison's gendered language of agency.

I want to suggest, eventually, that Ellison's novel demonstrates something more complex and salutary than "homophobic logic," but it is true that the scene with young Emerson gives little sense of this critique-to-come. ${ }^{5}$ In fact, although Kim passes over without comment Ellison's inclusion of a copy of Totem and Taboo in this scene, Freud's study relates specifically to young Emerson's homosexuality. ${ }^{6}$ In Totem and Taboo, Freud offers a notoriously fantastic theory of the primal institution of the heterosexual, non-incestuous symbolic economy. Briefly, Freud posits a moment in human prehistory when "a violent and jealous father" decided to keep all of the horde's females for his own pleasure, thereby excluding all of his sons from sexual enjoyment (Totem 175). Living in exile, the brothers plot to do together what they could not do individually: overthrow their father and claim the women for themselves. Freud postulates that the band of brothers then killed the father and, being cannibals, ate him. This consumption completes each brother's identification with his father and symbolizes his appropriation of a portion of his father's strength. However, this thorough identification with the father, the act of literally internalizing him, leads to the father's becoming even stronger in death than in life. The brothers therefore repeat the father's injunction against incestuous enjoyment by "freely" renouncing their claim to the women they have won. "Sexual desires do not unite men but divide them" (178), in Freud's view, so the brothers must renounce their own women and institute extratribal exchange in order to preserve social unity: "In this way they rescued the organization which had made them strong-and which may have been based on homosexual feelings and acts, originating perhaps during the period of their expulsion from the horde" (179). In other words, Totem and Taboo postulates male homosexuality's sublimation as enabling the emergence of a nonincestuous and heterosexual society of "brothers." The residue of that sublimated homosexuality would thus be "homosociality."7

My suggestion is that the significance of Totem in Chapter 9 derives to an important degree from a repugnant belief that homosexuality is a kind of socially castrating dysfunction and from the fear, therefore, that effeminacy and homosexuality might be associated with black men, as they recently had been in Leslie Fiedler's 1948 interpretation of Huckleberry Finn, "Come Back to the Raft Ag'in, Huck Honey!" Thus, a "thwarted" but "elegant" young Emerson minces, flutters, and seems "near tears," because he lives the homosexuality that Freud theorizes as a sublimated element of productive male-to-male interaction (IM 180f). In Ellison's description, he is pathetically effeminate because he does not participate in the exogamic "traffic in women" that Totem theorizes, and he is therefore undergoing therapy. Indeed, in "TwentiethCentury Fiction and the Black Mask of Humanity" (1953), Ellison suggests that 


\section{A L L A L O O}

"problems" like homosexuality are also at the origin of a microsocial event such as a work of art:

in its genesis the work of art, like the stereotype, is personal; psychologically it represents the socialization of some profoundly personal problem involving guilt (often symbolic murder-parricide, fratricide-incest, homosexuality, all problems at the base of personality) from which by expressing them along with other elements (images, memories, emotions, ideas) he [the artist] seeks transcendence. (SA 38-39, italics added)

It is tempting to offer sublimation as an alternative word choice for transcendence in this passage, for both Totem and Taboo and Ellison understand incest and homosexuality as similarly, if not simultaneously, "transcended" through socialization. In addition, for any reader aware of the cultural context that Ellison's novel comes out of-that of the Harlem Renaissance and a long-standing racist association in many whites' minds between blackness and sexual availability-young Emerson's "impure" motives (186) and his contemptible failure to transcend homosexuality are strategically linked: Emerson sexualizes the narrator's race in much the way that Carl Van Vechten might have, and Ellison presents the erotic interest as contemptible. ${ }^{8}$

Just as there was a mirroring effect when the narrator looked at the naked blonde and saw a figure of his own terror and castration, so does he here see a mirror of his own incapacity for having a relationship with a woman. Ellison deliberately designed this character trait of the narrator's as "funny," noting that he "felt that such a man as this character would have been incapable of a love affair; it would have been inconsistent with his personality" (SA 180). It seems probable that many readers also snicker at young Emerson, who is "funny" in a queer way. At any rate, faced with a white homosexual, the narrator flees racial (homo)sexualization, which the battle royal scene had associated with woman's castration and which Ellison has described as a failure of socialization. It is no idle pun on castration to say that the narrator is "cut off" by Bledsoe's letter in this scene, nor does it seem accidental that it is the ineffectual young Emerson who gives the narrator this letter to read. Still under his father's thumb, young Emerson is not really a party to the homosocial brotherhood that Freud considers the afterimage of a sublimated primary homosexuality. The significance of Totem in this scene is thus not that Freud's study describes young Emerson (as Alan Nadel has wrongly suggested [128]), but that it does not describe him: he has not sublimated or transcended his homosexuality and therefore represents the supposed danger of a paternally castrated and non-agentive relation to language and male privilege that fails to affirm its agency through the symbolic abjection of the feminine. In a passage that illuminates the homophobic logic at work here, Lacan goes so far as to argue that "the symbolic isolation of the 'I am not castrated,' in which the subject asserts himself, [is] the compulsive form in which his heterosexual choice remains riveted, in opposition to the homosexualizing capture undergone by the ego when brought back to the imaginary matrix of the primal scene" (Écrits 264; ÉS 55). For both Ellison (in this scene) and Lacan, the masculine subject 


\section{A L L A L O O}

maintains its distinction from the feminine through its adherence to the apotropaic gesture of compulsively negating its own symbolic castration; it is this negation that installs the illusion of hetero-phallic agency. Thus, the homosexual young Emerson despairs of his agency as a speaking subject and laments: "If I could only speak plainly!" (IM 186). Speak plainly, though, neither young Emerson nor the narrator will ever learn to do.

\section{Sybil and the Santa Claus Surprise}

However, the narrator will gain employment as an effective speaker with the Brotherhood (though the effects of his speech are never quite what he intends). When the narrator is inducted into the Brotherhood at the Chthonian, a woman named Emma plays a significant role in his introduction to and circulation among the other men. Indeed, Emma's purpose seems to be precisely to lubricate the men's interactions, since she welcomes the narrator $(300)$, serves drinks $(302,310)$, hands the narrator his new Brotherhood name (309), and distributes money (310)—all, of course, according to Brother Jack's instructions. Emma, however, proves to be more than the narrator can handle, and there are immediate signs of this. For example, when Emma looks at the invisible man he feels that "[i]t was not the harsh uninterested-in-you-asa-human-being stare that I'd known in the South, the kind that swept over a black man as though he were a horse or an insect; it was something more, a direct, what-type-ofmere-man-have-we-here kind of look that seemed to go beneath my skin . . Somewhere in my leg a muscle twitched violently" (302). In addition, Emma skeptically questions whether he shouldn't be "a little blacker" (303) and challenges him to fence with her (512). Such "boldness" (512) signals Emma's adoption of a relatively phallic stance, since she scopically judges the narrator's inadequacy (which his twitching leg registers as an impotence) and flaunts her own phallic agility with a rapier. Eventually, the narrator will decide that to outsmart the Brotherhood at its own game, he will need to use a woman as a conduit of information. His first thought is to use Emma in this way, but he senses that she is too "hard," a strange reversal of his first impression of her "perfumed softness" $(515,300)$.

Instead, he lights on a less phallic woman, Sybil, and in this passage Ellison begins to undo the hetero- and phallocentric logic of agency that has so far subtended the novel. Although the narrator intends to manipulate his affair with Sybil in order to subvert the Brotherhood and "seize some instrumentalities of political power" (GT 62 ), if we keep in mind the kind of dynamic of exogamic exchange theorized by Freud, then he is at no point more a member of the Brotherhood than when he decides to use Sybil as a medium of exchange. The narrator feels that "somewhere between Rinehart and invisibility there were great potentialities" (510-11), and in order to explore these he wracks his mind for the means of obtaining information on the Brotherhood's strategies. Finally, he realizes: "It called for a woman. A wife, a girl friend, or secretary of one of the leaders, who would be willing to talk freely to me" (512). The woman is thus to serve the narrator as an instrument in his interactions with the upper echelons 


\section{A L L A L O O}

of the Brotherhood, and he conceives of her as having only the agency of an inanimate tool-that is, none without his manipulation. As Sylvander observes, Sybil apparently has "no real mind" (78). Whereas he is frightened by Emma's subtle phallicism, Sybil will apparently serve as a pure medium of exchange. Just as the narrator has consistently mistaken the symbolic structure of language as a pliable instrument for the transmission of a transparent message that he controls, so does he view Sybil as a subornable device, an agent (instrument) without agency (intention and power).

Ultimately, however, this logic of exchange (in order to achieve agency, the control of instrumentalities of power) is shown to be as much an illusion as his earlier belief that his speaking abilities were a clear avenue to political agency, for Sybil naïvely reminds the narrator that he is not symbolically positioned simply as a man but as a black man. Indeed, it quickly becomes apparent that Sybil is only interested in the invisible man because he fits into the "little dramas which she had dreamed up around the figures of Joe Louis and Paul Robeson" (516). The narrator recalls that "it became quite a contest, with me trying to keep the two of us in touch with reality and with her casting me in fantasies in which I was Brother Taboo-with-whom-all-things-arepossible" (517), a name that humorously echoes both the Trueblood episode and the brotherly incest of Totem and Taboo. The situation's absurdity, from the narrator's perspective, escalates when Sybil requests that he kindly rape her like the brute he is. It is at this point that the narrator, quite shocked by the "revolting ritual" she has requested, feels fully alienated from his own goals and recounts: "I could not tell if it were horror speaking to me out of innocence, or innocence emerging unscathed from the obscene scheme of the evening" (517). The narrator's scheme has thus been wholly subverted by the fantasy scenario that he has found himself in, the easy distinction he had been making between reality and fantasy disappears, and the tricky agency of the "obscene scheme" itself seems to take over and ruin his plans.

Among the strangest of the narrator's experiences in Invisible Man, the sex scene with Sybil revisits the symbolic castration of the battle royal scene, in which the narrator and the other boys had faced the contradictory demands of the town patriarchs to look and not to look at the naked blonde. In that scene, the boys did have erections, but these were gratifying only to the white men, for whom they served as a negative image of their own phallic potency. In this scene, Ellison unveils the phallus itself as a fraud when he exposes the illusion of the narrator's activity as a man. On the one hand, it would seem that nothing could be more "actively" phallic than rape, nothing a more convincing sign of his own black hetero-phallic freedom than a subordinate "cock-hungry" white woman. However, Sybil puts her finger on the narrator's identification with herself (and, implicitly, with the naked blonde) when she says, "[Y]ou're not like other men. We're kind of alike" (520). In this vein, Catherine E. Saunders notes that "he is plagued by the sense of responsibility he felt earlier: the sense that black men, steeped in white stereotypes, may finally become what they are told they are" (17). Given the choice between being "like" women (castrated) or miming the stereotype of the brutishly virile black man, the narrator elects to play the part of the "domesticated rapist" (IM 521). He alters his speech and behavior, growling "I rapes real good when I'm drunk!" and becoming "annoyed enough to slap her" $(521,522)$. Still, his adoption of the role to which he has been called 


\section{A L L A L O O}

is not a testament to his masculinity. On the contrary, as Radford contends, the narrator's interpellation into this role means that he is "effectively emasculated as a sexual individual by total absorption into the white myth" (230).

Thus, when the moment comes to rape Sybil, the narrator asserts his agency by literarily rather than literally raping her: political action, which has already been displaced to sexual action, is thus further displaced to a hermetic symbolic gesture. Instead of actually having sex with Sybil, he seizes her lipstick and writes on her belly (522):

\section{SYBIL, YOU WERE RAPED \\ BY \\ SANTA CLAUS \\ SURPRISE}

This is surely one of the novel's most surreal moments and one that seems to have stumped most commentators, who (if they refer to it at all) tend merely to cite the strange graffito without offering an interpretation. In this context, two complementary resources suggest themselves. First, in Screening the Blues, Paul Oliver records numerous uses to which the figure of Santa Claus was put during the 1920s and 1930s. ${ }^{9}$ For instance, he draws attention to a moralistic use in religious contexts, where his figure was invoked as an ominous one that might bring punishment, even death, to those who failed to behave properly (31). Oliver also relates that "Bo Carter gave a new twist to the theme by obscurely hinting that Santa Claus was [...] an unspecified sexual symbol" (40), as these lyrics intimate:

Now I'm gonna use your Santa Claus several different ways, I'm gonna use your Santa Claus baby both night and day, Baby, please let your Santa Claus come down the chimney to me tonight,

Because I believe what Santa Claus gonna bring me will just suit my appetite.

Oliver's research usefully demonstrates the representational mobility of the Santa Claus figure in the cultural context out of which Ellison's novel comes and reinvests the excessively jolly gift-giver with some of the sinister surrealism that innumerable reiterations of the figure as a commercial banality have today vitiated. Viewed as a superegoic Grim Reaper or an obscure object of sexual desire, Santa appears quite differently in the Sybil scene than he does if we conceive of him as the rather dull marketing gimmick he has become. On the one hand, Santa is the cruel father that enforces symbolic law, but on the other he is the very object that sets desire in motion. The protean Santa that emerges in Oliver's research paradoxically represents not only a stern paternal law but also the promise of sexual enjoyment beyond that law.

At a more abstract level, Lacan's work, too, offers a specific allusion to the hallucinatory quality of the Santa figure that illuminates the narrator's odd inscription. In a passage that should give pause to those who see in Lacan an unquestioning 
adherent of the phallocentric sexual regime that he theorizes, Lacan argues that a cultural phenomenon such as that of le père Noël ('Father Christmas') is a "social psychosis" that, while "compatible with what is called good order," should cause analysts to question the very cultural discourses that support their work (Écrits 576; $E ́ S$ 216). In other words, the figure of Santa Claus, which in French frankly declares itself a father figure, represents the delusional promise of fulfillment that culture in its symbolic structure holds out to the subject. As Alan Sheridan comments in his gloss of Lacanian terminology at the beginning of Écrits: A Selection, "that which comes from the Other is treated not so much as a particular satisfaction of a need, but rather as a response to an appeal, a gift, a token of love" (viii, italics added). For Lacan, however, this gift or token of love is never exactly what was demanded. Although the symbolic pretends to proffer full enjoyment, it never delivers it: the arrival of the real gift is never on time. Insisting that the symbolic mandates the pursuit of desire, Lacan punningly writes that the law of the symbolic, rather than repressing desire, commands: "Jouis" ['Enjoy'] to which the miming subject must reply: "J'ouïs" ['I hear'] (Écrits 821; ÉS 319). Although "[t] he true function of the father [...] is fundamentally to unite (and not to set in opposition) a desire and a Law" $(824 ; 321)$, this does not mean that a desire united to symbolic law will be fulfilled. On the contrary, the ego comes to exist in an endless metonymy from one signifier to the next $(809 ; 307)$, never arriving at possession of the object $a$, the obscure cause of desire. For Lacan, the lover's (or analysand's) promise is always: "I give myself to you, [. . . ] but this gift of my person-[.. . . Oh, mystery! is changed inexplicably into a gift of shit" (SXI 299; FFC 268 , italics suppressed). Love and its physical expression in sex are, then, the ultimate trick, as the slang of prostitutes and queers suggested long ago, since what appears to be a precious and intimate gift is never fully satisfactory. Whether in the form of Santa Claus or the novel's several male representatives of phallic ideology, the "father" holds out promises he cannot and will not fulfill.

Thus, for the narrator, Sybil is his "too-late-too-early love" (528) and represents something she cannot deliver, and for Sybil, the narrator is her rapist "daddy" and represents something that he cannot deliver: the full satisfaction of a fantasy. ${ }^{10}$ Both characters project a fantasy image onto the other person, misrecognizing the other as that which can fulfill a deep desire, just as Santa Claus is himself an impossible fantasy figure that makes untenable promises of obscene gratification. To emphasize the quirky libidinal nature of the encounter, Ellison describes the act of writing and erasing the graffito in sexual terms. Seizing Sybil's lipstick, a small "purplish" phallus, the narrator begins to write, while Sybil drunkenly encourages him as though they are engaging in sex: "'Hurry, boo'ful, hurry,' she said." Underscoring his phallic failure to perform adequately, though, the narrator remarks: "She lay anonymous beneath my eyes until I saw her face, shaped by emotions which I could not fulfill, and I thought, Poor Sybil, she picked a boy for a man's job." Indeed, although Sybil had "panted with anticipation," we are told that "she didn't arouse" until the narrator has nearly finished erasing the traces of his scripted, symbolic rape: the event has been all anticipation and no climax for Sybil. In fact, in the end, Sybil has not been raped as she desired, and the narrator has not gained the information he sought. Their alluring gift boxes have turned out to be empty-or, worse, to have racist/sexist shit in them. So, 


\section{A L L A L O O}

when Santa Claus finds himself inscribed as a lipstick clause on Sybil's belly, a purplish smear soon erased, the evanescence of this "luminescent sign" confirms the failure of perverse desire to find its fulfillment in the phallus or any object $a$. Sybil and the narrator are the puppets of a castrating and tricky cultural network the opacity of which has led them mistakenly to see in each other the flickering sign of their own promised fulfillment. Although the narrator intended to use Sybil sexually as a political instrument, the heterosexual fantasy scenario in which he finds himself caught up ultimately reveals his supposed hetero-phallic agency as a lipstick masquerade, an illusion that he himself wipes out as if to avoid the surprising evidence of his own agentive lack and to avoid the further castrating effects that Sybil's husband might visit on him. ${ }^{11}$

\section{Whiteness and The Illusions of Phallic Agency}

The encounter with Sybil thus irretrievably complicates the "latent homophobic logic" that Kim rightly reads in some passages of the novel, for the encounter with Sybil shows the narrator's hetero-phallic status as a political agent to be as much an illusion as Santa Claus' promises of gratification. But even that strange sexual encounter is not the novel's most unambiguous rejection of the illusions of phallic agency. Rather, the most striking passage to make this rejection occurs near the novel's end during a dream sequence in which the novel's major male figures reappear in order to force the invisible man to return to them. He refuses, stating that he is through with their illusions. "Refuse," Brother Jack threatens, "and we'll free you of your illusions all right" (569). The narrator continues to resist:

But now they came forward with a knife, holding me; and I felt the bright red pain and they took the two bloody blobs and cast them over the bridge, and out of my anguish I saw them curve up and catch beneath the apex of the curving arch of the bridge, to hang there, dripping down through the sunlight into the dark red water. [...] 'Now you're free of illusions,' Jack said, pointing to my seed wasting upon the air. 'How does it feel to be free of one's illusions?' [. . .] I answered, 'Painful and empty,' as I saw a glittering butterfly circle three times around my blood-red parts, up there beneath the bridge's high arch. (569)

In this passage, the invisible man finally, fully traverses the racist and phallocentric fantasies that have stymied his progress up to this point in the novel. To the men's dismay, he begins to laugh. He says, "at a price I now see that which I couldn't see," then points toward his testicles hanging from the bridge and adds: "But if you'll look you'll see... It's not invisible ... [...] That there hang not only my generations wasting upon the water-[...] But your sun [...] And your moon ... [...] Your world ..." (569, 570). The castration in this surreal passage most clearly communicates the novel's critique of the invisible man's earlier phantasmatic reliance on the phallic function in 


\section{A L L A L O O}

articulating his own notion of himself as a social agent. In addition, it exposes the whiteness of the phallic function when the invisible man declares that his castration is the other men's sun, moon, and world: in other words, that his symbolic castration as a black man supports the phantasm of universal (white) social agency. Whereas in the "The Birthmark" Ellison's protagonists were unambiguously defeated by racialized castration, the invisible man here gains an uncanny victory through affirming it.

Scenes such as that with Sybil and the dream sequence, in which the narrator continues to resist his cultural inscription but again fails to access the kind of political agency he has sought throughout the novel, are the most spectacular instances of Ellison's exploration of the symbolic castration that the invidious cultural network of sexualized racism enacts on the black male body. Trapped in a perceived choice between (1) being socially castrated like a woman or a homosexual and (2) adhering to the stereotype of the brutishly virile black male, the invisible man chooses to mime the stereotype, only to find that there really was no choice; he is castrated either way. In his effort to access instrumentalities of political power via the dehumanizing exchange of a woman and the "transcendence" of homosexuality, the narrator discovers yet again what Ellison would continue to emphasize in later work: "the Word is tricky!" (Ellison, Juneteenth 360). On the field of discursive constraints that the narrator traverses, he continually confronts the inscription of black male gender and sexuality in an enigmatic and racist discourse (the Lacanian Other) that deprives him of transparent intentional agency. As Slavoj Zizek argues, "Racism confronts us with the enigma of the Other, which cannot be reduced to the partner in symbolic communication," that is, to an individual such as young Emerson or Sybil. Rather, "it confronts us with the enigma of that which, in ourselves, resists the universal frame of symbolic communication" (155). This is not to say that the narrator has no agency (since hetero-phallic agency is a ruse of power), but to complicate our view of his agency. His agency, such as it is, derives not from the phallus but from his interventions in discourse, his symbolic action. Against a simplistic assimilation of Ellison to the liberal humanist voluntarism of his day, I argue for a reading of Ellison's work that is consistent with his own contention that:

language is the primary agency of order. Why? Because it is the identifying characteristic of a symbol-using, symbol-misusing animal. It is through language that man has separated himself from his natural biologic condition as an animal, but it is through the symbolic action, the symbolic capabilities of language, that we seek simultaneously to maintain and evade our commitments as social beings. (GT 329)

In this passage Ellison calls for an analysis that would allow us to understand more fully how our own particular freedoms and responsibilities are articulated in the same impersonal practices of subjectification that empower some at the expense of others. This analysis must take language and representation as the primary field of agency, since it is social discourse - the tricky Word-that structures and sustains our relation to the grit of material reality. Indeed, one of the great lessons of Invisible Man is that 
agency is wholly representational: even when individuals are trapped in physically violent and degrading situations, those situations are only visible as symbolic scenarios. For the narrator of Invisible Man, the abjection of women and homosexuals operates at first as a discursive strategy for making the black male's position more subjectively endurable, but the narrator must eventually confront this discursive strategy as an illusion of hetero-phallic agency, since he continually fails to acquire the sorts of instrumentalities of power associated with directly political speech. In the end, he recognizes possession of the phallus as a myth on the order of Santa Claus and opts for a more obviously representational, but less obviously political, discourse: his narrative. If we are to take the novel itself as the evidence of the invisible man's agency, though, then this agency is entirely representational: it acts in and on the world only as a shifty fiction, a tricky Word.

\section{NOTES}

1. For example, Gwen Berger offers a compelling intervention on this topic in her essay "Myths of Masculinity: The Oedipus Complex and Douglass's 1845 Narrative," arguing that in Douglass' work "slavery and femininity seem to correspond as do freedom and masculinity" (253).

2. In addition to Tate's important contribution, see Carolyn W. Sylvander, Janet Overmyer, Mary Rohrberger, Catherine E. Saunders, and Ann Folwell Stanford.

3. The interpretation of this scene as symbolic castration has become standard. George Kent, for instance, remarks that one of the most powerful folk motifs is the racial joke of black man and tabooed white woman. The unwritten folk joke, from which the scene derives, is concerned with a black man looking at a white woman and expressing sexual desire while a white man stands by and replies.

Black: Oh man, will I ever, ever!

White: No Nigger, you will never, never!

Black: As long as there's life there's hope!

White: Yeah Nigger, and as long as there's trees there's rope! (99)

The ritual is thus intended to impress upon the boys their symbolic castration when faced with a white woman. See also, Radford (228-29) and Fabre (122).

4. Mulvey's critics have understandably pointed out that her model seems to participate, reductively, in a patriarchal visual apparatus, since it positions woman as object and man as viewing subject. It should be remembered, however, that both Mulvey's and Lacan's analyses of the sexed character of the gaze do not attempt to theorize the mechanisms of an ideally egalitarian world but of a profoundly misogynist and heteronormative one, "a world ordered by sexual imbalance" (Mulvey 11). The task at the intersection of critical theory and cultural studies today is to appropriate and renovate these useful theoretical models in the interest of challenging that imbalance.

5. It is interesting to note that Ellison himself, at least at one point, explicitly intended Emerson's homosexuality to enable a sympathetic "identif[ication] with the boy's Negro status" (Ralph Ellison Papers). Indeed, Ellison considered having young Emerson at work on a biography of Whitman that would show a "connection between Whitman's homosexuality and his change in attitude toward Negroes. [Emerson had h] eard that the bard had been far less interested before, had even written against Negroes up to that point. / Perhaps not" (spelling silently corrected). Ellison's final "Perhaps not" is a telling indication of his ambivalence about such a sympathetic black/gay identification.

6. Whereas Kim passes over Totem's presence in this scene, Caffilene Allen has extensively explored the significance of Freud's book for Invisible Man. However, her insistence on primitivism disregards Ellison's gendered diction as well as the homosociality in Freud's text.

7. On this term, see, for instance, the introduction to Eve Kosofsky Sedgwick's Between Men: English Literature and Male Homosocial Desire. 


\section{A L L A L O O}

8. In fact, Kim suggests that Van Vechten could be the model for young Emerson: "Both figures are gay, share an erotic interest in black men, and are collectors of exotic objects" (319n10).

9. Eric J. Sundquist's allusion to this resource in his introduction to the Bedford volume Cultural Contexts for Ralph Ellison's Invisible Man first drew my attention to it (25).

10. Unless otherwise indicated, all quotations in this paragraph are from pages 522-23.

11. This lipstick masquerade, curiously enough, perhaps sheds some light on the enigmatic Lacanian principle that "virile display itself appears as feminine" (Écrits 695; FS 85).

\section{WORKS CITED}

Allen, Caffilene. “The World as Possibility: The Significance of Freud's Totem and Taboo in Ellison's Invisible Man." Literature and Psychology 41 (1995): 1-17.

Benhabib, Seyla, et al. Feminist Contentions: A Philosophical Exchange. New York: Routledge, 1995.

Benston, Kimberly W., ed. Speaking for You: The Vision of Ralph Ellison. Washington, DC: Howard University Press, 1987.

Berger, Gwen. "Myths of Masculinity: The Oedipus Complex and Douglass's 1845 Narrative." The Psychoanalysis of Race. Ed. Christopher Lane. New York: Columbia University Press, 1998. 24160.

Butler, Judith. "Dynamic Conclusions." Contingency, Hegemony, Universality: Contemporary Dialogues on the Left. By Judith Butler, Ernesto Laclau, and Slavoj Zizek. London: Verso, 2000. 263-80.

Christian, Barbara. "The Race for Theory." Cultural Critique 6 (1987): 51-63.

Ellison, Ralph. "The Birthmark." New Masses (2 July 1940): 16-17.

- - Going to the Territory [GT]. New York: Vintage, 1986.

___. Invisible Man [IM]. New York: Vintage, 1952.

—_- Juneteenth. Ed. John F. Callahan. New York: Random House, 1999.

. "Out of the Hospital and Under the Bar." Soon, One Morning: New Writing By American Negroes. Ed. Herbert Hill. New York: Knopf, 1968. 244-90.

. Ralph Ellison Papers, Container 144, Folder 5. Manuscripts Division, Library of Congress, Washington, DC.

Shadow and Act [SA]. New York: Vintage, 1964.

Fabre, Michel. "Looking at the Naked Blond-Closely (or Scrutinizing Ellison's Writing)." Delta 18 (1984): 119-31.

Fiedler, Leslie. “Come Back to the Raft Ag'in, Huck Honey!” Partisan Review 15 (1948): 664-711.

Fraser, Nancy. "False Antitheses: A Response to Seyla Benhabib and Judith Butler." Feminist Contentions: A Philosophical Exchange. Ed. Seyla Benhabib, et al. New York: Routledge, 1995. 5974 .

Freud, Sigmund. Totem and Taboo: Some Points of Agreement Between the Mental Lives of Savages and Neurotics. Trans. James Strachey. New York: Norton, 1950.

Kent, George E. "Ralph Ellison and Afro-American Folk and Cultural Tradition." Speaking for You: The Vision of Ralph Ellison. Ed. Kimberly W. Benston. Washington, DC: Howard University Press, 1987. 95-104.

Kim, Daniel Y. "Invisible Desires: Homoerotic Racism and Its Homophobic Critique in Ralph Ellison's Invisible Man." Novel 30 (1997): 309-28.

Lacan, Jacques. Écrits. Paris: Seuil, 1966. Écrits: A Selection [ÉS]. Trans. Alan Sheridan. New York: Norton, 1977.

. Le Séminaire XI: Les Quatre Concepts fondamentaux de la psychanalyse [SXI]. Paris: Seuil, 1973. The Four Fundamental Concepts of Psycho-Analysis [FFC]. Ed. Jacques-Alain Miller. Trans. Alan Sheridan. New York: Norton, 1977.

Lacan, Jacques, and the École freudienne. Feminine Sexuality [FS]. Eds. Juliet Mitchell and Jacqueline Rose. Trans. Jacqueline Rose. New York: Norton, 1982.

Lane, Christopher. The Psychoanalysis of Race. New York: Columbia University Press, 1998.

Mulvey, Laura. "Visual Pleasure and Narrative Cinema." Screen 16.3 (1975): 6-18.

Nadel, Alan. Invisible Criticism: Ralph Ellison and the American Canon. Iowa City: University of Iowa Press, 1988.

Oliver, Paul. Screening the Blues: Aspects of the Blues Tradition. New York: Da Capo, 1968.

Overmyer, Janet. "The Invisible Man and White Women." Notes on Contemporary Literature 6.3 (1976): $13-15$. 


\section{A L L A L O O}

Radford, Frederick L. “The Journey Towards Castration: Interracial Sexual Stereotypes in Ellison's Invisible Man." Journal of American Studies 4 (1971): 227-31.

Rohrberger, Mary. “'Ball the Jack': Surreality, Sexuality, and the Role of Women in Invisible Man." Approaches to Teaching Ellison's Invisible Man. Ed. Susan Resneck Parr and Pancho Savery. New York: MLA, 1989. 24-32.

Saunders, Catherine E. "Makers or Bearers of Meaning? Sex and the Struggle for Self-Definition in Ralph Ellison's Invisible Man." Critical Matrix 5 (1989): 1-28.

Sedgwick, Eve Kosofsky. Between Men: English Literature and Male Homosocial Desire. New York: Columbia University Press, 1985.

Stanford, Ann Folwell. "He Speaks for Whom?: Inscription and Reinscription of Women in Invisible Man and The Salt Eaters." MELUS 18.2 (1993): 17-31.

Sundquist, Eric J. "Introduction." Cultural Contexts for Ralph Ellison's Invisible Man. Ed. Eric J. Sundquist. Boston: Bedford, 1995. 1-28.

Sylvander, Carolyn W. "Ralph Ellison's Invisible Man and Female Stereotypes." Negro American Literature Forum 9 (1975): 77-79.

Tate, Claudia. "Notes on the Invisible Women in Ralph Ellison's Invisible Man." Speaking for You: The Vision of Ralph Ellison. Ed. Kimberly W. Benston. Washington, DC: Howard University Press, 1987. 163-72.

Zizek, Slavoj. "Love Thy Neighbor? No, Thanks!" The Psychoanalysis of Race. Ed. Christopher Lane. New York: Columbia University Press, 1998. 154-75. 